\title{
Plastic scintillators for thermal neutrons detection
} \author{
I.B.Nemchenok ${ }^{* * *}$, N.A.Gundorin ${ }^{*}$, E.A.Shevchik
A.A.Shurenkova \\ *Joint Institute for Nuclear Research, 6 Joliot Curie St., \\ Dubna, Russia \\ "Dubna" University, 19 Universitetskaya St., Dubna, Russia
}

Received March 11, 2013

\begin{abstract}
The new cadmium and gadolinium-loaded polymethylmethacrylate based plastic scintillators with the mass fraction of the metals up to $2 \%$ and $4 \%$, respectively, are described in this article. There are presented the techniques of the new materials preparation and their main properties: transmission spectra, light output and thermal neutrons detection efficiency. The light output of Cd-loaded scintillator with $2 \%$ of metal is $67 \%$ relative to the unloaded sample; the light output of Gd-loaded plastic scintillator with $4 \%$ of the metal is reduced to $67.6 \%$. There is regular increase of the thermal neutrons detection efficiency for the both series of the scintillation materials.
\end{abstract}

Описаны новые кадмий- и гадолинийсодержащие пластмассовые сцинтилляторы на основе полиметилметакрилата с массовой долей металла, достигающей $2 \%$ и 4 \% соответственно. Представлены методики получения новых материалов и их основные характеристики: спектры пропускания, результаты измерения световыхода и әффективности регистрации тепловых нейтронов. Световыход сцинтиллятора, содержащего $2 \%$ кадмия, составляет $67 \%$ относительно несодержащего металл образца; световыход гадолинийсодержащего пластмассового сцинтиллятора с 4 \% металла, снижается до $67.6 \%$. В обеих сериях сцинтилляционных материалов наблюдается закономерное увеличение эффективности регистрации тепловых нейтронов.

Пластмасові сиинтилятори для реєстрації теплових нейтронів. І.Б.Немченок, Н.А.Гундорін, С.А.ШЕевчик, А.А.Шуренкова.

Описано нові пластмасові сцинтилятори, які містять кадмій і гадоліній, на основі поліметилметакрилату з масовою часткою металу, що досягає $2 \%$ і $4 \%$, відповідно. Представлено методики отримання нових матеріалів і їх основні характеристики: спектри пропускання, результати вимірювання світловиходу і ефективності реєстрації теплових нейтронів. Світловихід сцинтилятора, що містить $2 \%$ кадмію, складає $67 \%$ щодо зразка, що не містить метал; світловихід гадолінійвмісного пластмасового сцинтилятора з 4\% металу, знижується до $67.6 \%$. В обох серіях сцинтиляційних матеріалів спостерігається закономірне збільшення ефективності реєстрації теплових нейтронів.

\section{Introduction}

Fundamental and applied problems of modern physics motivate the development and improvement of currently known scintillation materials, including scintillators for thermal neutrons detection. Organic scintillators (OS), liquid (LS) and plastic scintillators (PS), are especially popular in this relation. They have plenty of advantages such as: high transparency, high radiation resistance, relatively low cost and simplicity of detectors creation with any shape, configuration and volume.

Being composed of carbon and hydrogen, organic scintillators are the most sensitive 
Table 1. Main characteristics of the new Cd-PS

\begin{tabular}{||c|c|c|c|c|c||}
\hline Parameter & \multicolumn{5}{|c||}{ Mass fraction of cadmium, \% } \\
\cline { 2 - 6 } & 0 & 0.5 & 1 & 1.5 & 2 \\
\hline Transmission $(\lambda=420), \%$ & 82.86 & 76.06 & 69.35 & 67.95 & 64.60 \\
Density, $\mathrm{g} / \mathrm{cm}^{3}$ & 1.170 & 1.167 & 1.168 & 1.150 & 1.146 \\
Relative light output, \% & 100 & 84.30 & 78.95 & 70.73 & 67.22 \\
$\begin{array}{c}\text { Efficiency of thermal neutrons } \\
\text { registration }(E \leq 0.5 \mathrm{eV}), \%\end{array}$ & 0 & $1.5 \pm 0.15$ & $2.4 \pm 0.24$ & $2.4 \pm 0.24$ & $6.8 \pm 0.68$ \\
$N(\mathrm{Cd})$, atoms $/ \mathrm{cm}^{3}, 10^{22}$ & 0 & 0.003 & 0.006 & 0.009 & 0.012 \\
$N(\mathrm{H})$, atoms $/ \mathrm{cm}^{3,} 10^{22}$ & 5.41 & 5.40 & 5.40 & 5.32 & 5.30 \\
\hline
\end{tabular}

* Relative to the unloaded plastic scintillator.

Table 2. The main characteristics of the new Gd-PS

\begin{tabular}{||c|c|c|c|c|c|c||}
\hline \multirow{2}{*}{ Parameter } & \multicolumn{7}{|c||}{ Mass fraction of gadolinium, \% } \\
\cline { 2 - 7 } & 0 & 0.5 & 1 & 2 & 3 & 4 \\
\hline Transmission $(\lambda=420), \%$ & 78.50 & 69.84 & 71.91 & 68.46 & 66.68 & 64.67 \\
Density, g/cm ${ }^{3}$ & 1.164 & 1.183 & 1.165 & 1.155 & 1.183 & 1.182 \\
Relative light output, \%* & 100 & 85.30 & 80.30 & 76.70 & 72.00 & 67.60 \\
Efficiency of thermal & 0 & $5.8 \pm 0.06$ & $10.3 \pm 1.03$ & $11.8 \pm 1.18$ & $12.8 \pm 1.28$ & $13.5 \pm 1.35$ \\
neutrons registration & & & & & \\
$(E \leq 0.5 \mathrm{eV}), \%$ & 0 & 0.0023 & 0.0045 & 0.0088 & 0.0136 & 0.0181 \\
$N(\mathrm{Gd})$, atoms $/ \mathrm{cm}^{3}, 10^{22}$ & 5.38 & 5.43 & 5.32 & 5.21 & 5.27 & 5.12 \\
$N(\mathrm{H})$, atoms $/ \mathrm{cm}^{3}, 10^{22}$ & &
\end{tabular}

* Relative to the unloaded plastic scintillator

to charged particles (electrons, protons, $\alpha$ particles, cosmic muons, etc.) and for neutrons with energies above $100 \mathrm{keV}$.

An increase of OS sensitivity to thermal neutrons is possible by doping wih the isotopes of elements with high thermal neutron capture cross-section, such as, for example, ${ }^{155} \mathrm{Gd},{ }^{157} \mathrm{Gd}$ and ${ }^{113} \mathrm{Cd}$ [1]. Cadmium and gadolinium compounds may be used without preliminary enrichment due to high content of these isotopes in the natural mixture. The molecular nature of luminescence of organic scintillators allows directionally modify the material properties without significant changing of their scintillation properties.

That is why gadolinium-loaded liquid scintillators (Gd-LS) are the base of a number of large-scale detectors in the field of neutrino physics: PALO VERDE [2-4], CHOOZ [5], DOUBLE CHOOZ [6-8], DAYA BAY [9, 10], RENO [11, 12].

As for the gadolinium-and cadmiumloaded plastic scintillator (Gd- and Cd-PS), an experience of their production is extremely poor. Information about Gd-PS is limited to three publications [13-15]. Plastic scintillators containing cadmium are not described in the literature at all.

The aim of the present research is to expand the number of organic scintillation materials for thermal neutrons detection.

Basing on our previous experience [15], we have prepared Gd- and Cd-loaded polymethylmethacrylate based PS with mass fraction of metal up to $4 \%$ and $2 \%$, respectively. The complex compounds of $\mathrm{Gd}$ and $\mathrm{Cd}$ chlorides with phosphoric acid hexamethylthriamide (HMPTA) were used as element-loaded additives.

\section{Experimental}

Initial materials. Standard methods were used for purification of the initial materials:

- cadmium and gadolinium chlorides was purified by recrystallization from ethanol;

- benzoyl peroxide - by recrystallization from methanol-chloroform mixture;

- methylmethacrylate and HMPTA were purified by distillation at atmospheric pressure and vacuum distillation, respectively. 


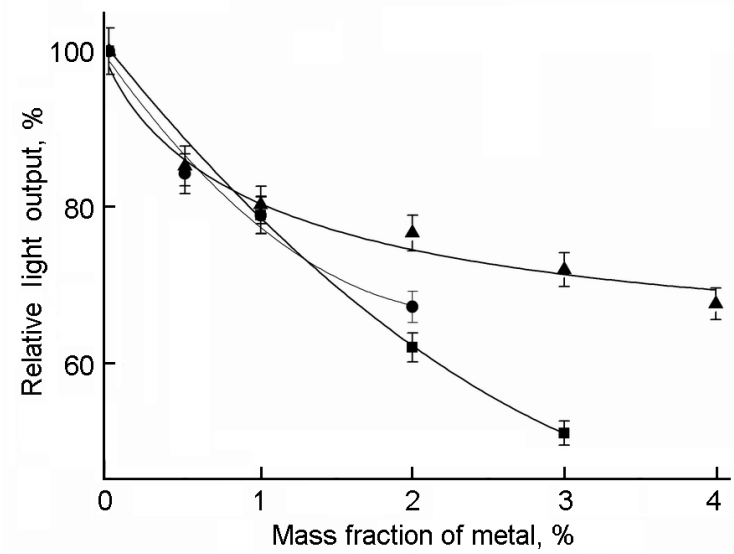

Fig. 1. Dependence of relative light output on mass fraction of the metal for Cd-PS (line with circles), and Gd-PS (line with triangles), and Gd-PS described in [15] (line with squares).

2,5-Diphenyloxazole (PPO) (reagentgrade qualification), 1,4-bis(5-phenyloxazol2-yl) benzene (POPOP) (reagent-grade qualification) and naphthalene (reagent-grade qualification) were used without additional purification.

Synthesis of Gd-loaded additive. A weighed portion of gadolinium chloride hexahydrate and dry toluene were placed into a round bottom flask. The flask equipped with a dropping funnel and a nozzle for water separation was placed to an oil bath. The mixture was boiled until the complete separation of the water. After this the appropriate amount of hexamethylphosphoramide (molar ratio of HMPTA: $\mathrm{GdCl}_{3}$ was 3.1:1) was added dropwise into the flask. The reaction mixture was heated until the complete separation of the water. The resulting solution was filtered and left to precipitate the crystals of the complex. The precipitate was filtered on a Buchner funnel and dried in a vacuum desiccator containing calcium chloride. The product was recrystallized from toluene and dried to constant weight in a vacuum desiccator.

The content of gadolinium chloride in the resulting compound corresponded to the composition [ $\left.\mathrm{Gd}(\mathrm{HMPTA})_{3} \mathrm{Cl}_{3}\right]$.

Obtaining of metal-loaded plastic scintillators. Gd- and Cd-loaded PS were produced by the bulk polymerization. HMPTA and cadmium chloride (molar ratio of HMPTA: $\mathrm{CdCl}_{2}$ was $4.1: 1$ ) or complex compound of gadolinium chloride with HMPTA, naphthalene (15\%), PPO (1.5\%), POPOP $(0.08 \%)$ and benzoyl peroxide $(0.1 \%)$ were dissolved in the preliminary measured

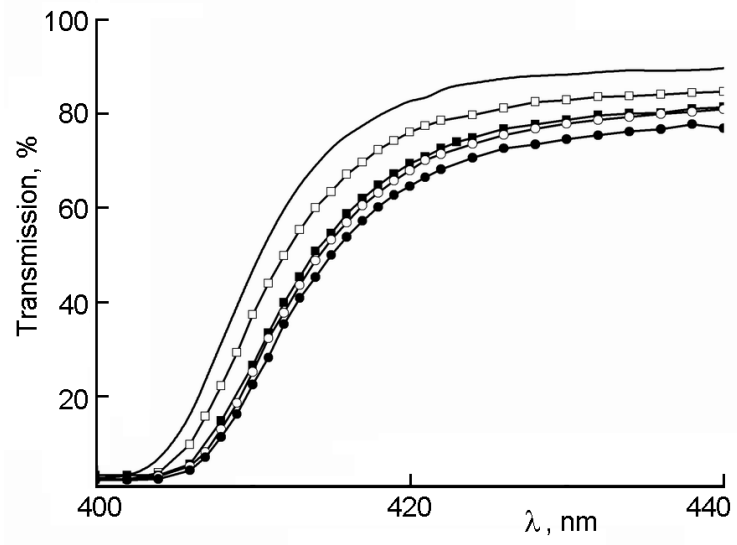

Fig. 2. Transmission spectra of Cd-PS samples with different mass fraction of cadmium (line without symbols $-0 \% \mathrm{Cd}$, open squares $-0.5 \% \mathrm{Cd}$, solid squares - $1.0 \%$ $\mathrm{Cd}$, open circles $-1.5 \% \mathrm{Cd}$, solid circles $2.0 \% \mathrm{Cd}$ ).

amount of methylmethacrylate. The resulting solutions were placed to glass vials which were carefully evacuated, filled with argon $(0.88$ bar $)$ and sealed. After this the vials were placed to polymerizer. When the polymerization completed, we used the scintillating plastics for producing the samples with the dimensions: $27 \mathrm{~mm}$ in diameter and $10 \mathrm{~mm}$ long. All the surfaces were thoroughly polished.

Method of measurement. Transmission spectra of the samples were measured by UNICO UV-2804 spectrophotometer relative to air with a scanning step of $1 \mathrm{~nm}$. Light output was measured as described in [15]. ${ }^{207} \mathrm{Bi}$ was used as a radioactive source. The efficiency of thermal neutrons registration was measured as described in [16].

\section{Results and discussion}

As a result of the polymerization process, two series of PS samples were obtained:

- Cd-loaded scintillators based on polymethylmethacrylate with the mass fraction of metal of $0 \%, 0.5 \%, 1 \%, 1.5 \%$ and $2 \%$;

- Gd-loaded scintillators based on polymethylmethacrylate with the mass fraction of metal of $0 \%, 0.5 \%, 1 \%, 2 \%$, $3 \%$ and $4 \%$.

Transmission spectra, light output and efficiency of registration of thermal neutrons were measured for all samples (the main characteristics of the new plastic scintillators are summarized in Tables 1 and 2.

The increase of the metal concentration in the both series of samples leads to a 


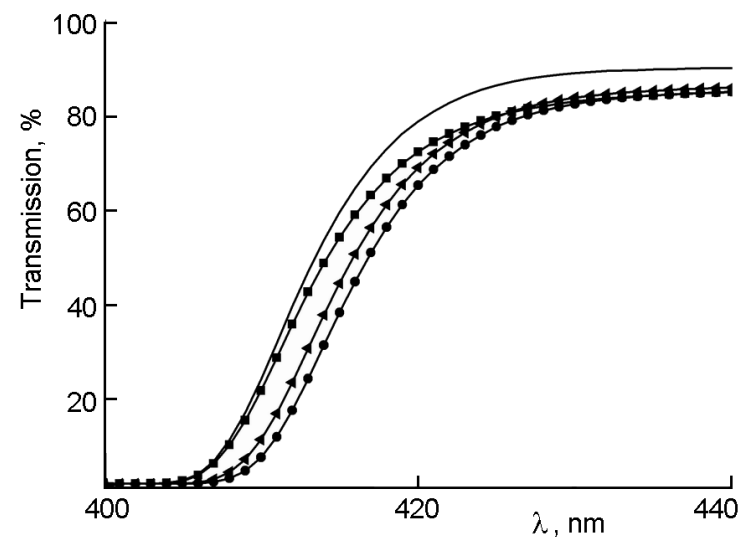

Fig. 3. Transmission spectra of Gd-PS samples with different mass fraction of gadolinium (line without symbols - $0 \% \mathrm{Gd}$, squares - $1 \% \mathrm{Gd}$, triangles - $2 \% \mathrm{Gd}$, circles $-4 \%$ Gd).

natural decrease of light output (Fig. 1, Tables 1 and 2). Light output of the scintillator with the maximum metal concentration is $67.0 \%$ for Cd-PS and $67.6 \%$ for Gd-PS, relatively to the metal-free sample. This effect is obviously due both to luminescence quenching, caused by the presence of metal, and reduction of the samples transparency (Fig. 2, 3). Comparing the obtained results with the results of [15] it was found that in the present study we could not only increase the metal content in Gd-PS samples, but also reduce the depression of light output by increasing the concentration of gadolinium (Fig. 1). Investigations of the efficiency of thermal neutron registration by the new materials (Fig. 4) showed that the rise of the mass fraction of cadmium leads to more than double increasing of this parameter. Introduction into plastic scintillator of $4 \%$ gadolinium leads to a fivefold increase of the registration efficiency for thermal neutrons. Its concentration dependence is identical to the data from [15].

\section{Conclusions}

As a result of the work done, cadmiumloaded plastic scintillators were produced for the first time and gadolinium-loaded ones were refined. The spectral and scintillation properties of the new materials were investigated. It was shown that increase of the mass fraction of the metals in both series of plastic scintillators leads on the one hand to decrease of the light output, on the other - to significant increase of the registration efficiency for thermal neutrons.

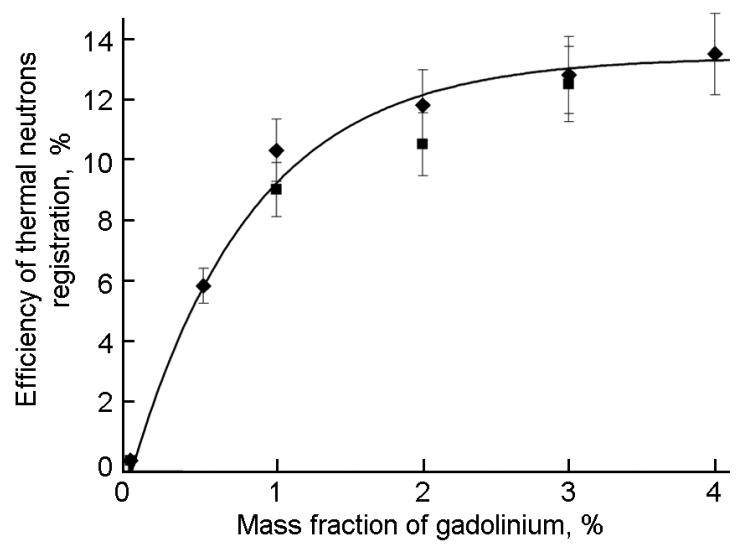

Fig. 4. Dependences of efficiency of thermal neutrons registration on mass fraction of the metal for Gd-PS (diamonds), and Gd-PS described in [15] (squares). The efficiency of thermal neutrons registration for the unloaded sample is taken as zero.

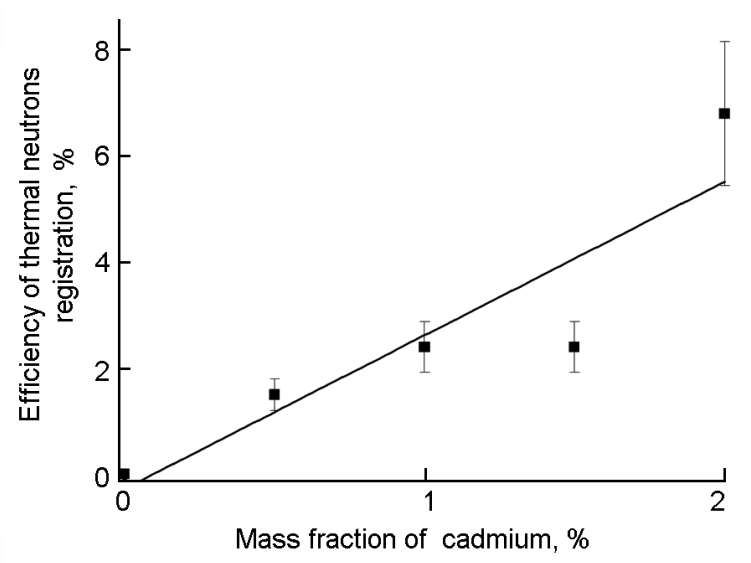

Fig. 5. Dependence of efficiency of thermal neutrons registration on mass fraction of the metal for Cd-PS. The efficiency of thermal neutrons registration for the unloaded sample is taken as zero.

This work was supported by the Russian Foundation for Basic Research, project No.10-02-91159 NSFC_a.

\section{References}

1. Tables of Physical Quantities. Handbook, ed. by the I.K.Kikoin, Atomizdat, Moscow (1976) [in Russian].

2. A.G.Piepke, S.W.Moser, V.M.Novikov, Nucl. Instr. Meth. Phys. Res. A, 432, 392 (1999).

3. F.Boehm, J.Buzenitz, J.Cornis et al., Nucl. Phys. B (Proc. Suppl.), 70, 191 (1999).

4. F.Boehm et al. (Palo Verde Collaboration), Phys. Rev. D, 62, 072002 (2000).

5. M.Apollonio, A.Baldini, C.Bemporad et al., Eur. Phys. J.C, 27, 331 (2003). 
6. Y.Abe, C.Aberle, T.Akiri et al., Phys. Rev. Lett., 108, 131801 (2012).

7. C.Buck, A.di Vacri, G.Mention et al., Nucl. Phys. B, 221, 372 (2011).

8. T.Akiri, Nucl.Phys.B (Proc.Suppl.), 215, 69 (2011).

9. F.P.An, Q.An, J.Z.Bai et al., Nucl.Instr.Meth. Phys. Res. A, 685, 78 (2012).

10. F.P.An, J.Z.Bai, A.B.Balantekin et al., Phys. Rev.Lett., 108, 171803-1 (2012).

11. J.K.Ahn, S.Chebotaryov, J.H.Choi, Phys. Rev. Lett., 108, 191802-1 (2012).
12. Soo-Bong Kim, Progr.Part.Nucl.Phys., 64, 346 (2010).

13. J.B.Gzirr, Nucl.Instr. Meth. Phys. Res. A, 108, 613 (1973).

14. V.I.Aleshin, A.M.Bakalyarov, A.Ya.Balysh et al., Pribory $i$ Tekhnika Eksperimenta, 4, 68 (1977).

15. V.B.Brudanin, V.I.Bregadze, N.A.Gundorin et al., Part. Nucl. Letters, 109, 69 (2001).

16. Y.Ding, N.A.Gundorin, Z.Zhang et al., Functional Materials, 16, 73 (2009). 